\title{
COMMUNITY STRUCTURES OF MID-SIZED TO LARGE-BODIED MAMMALS IN TROPICAL LOWLAND AND LOWER MONTANE FORESTS IN GUNUNG PUEH NATIONAL PARK, WESTERN SARAWAK, BORNEO
}

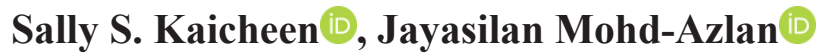 \\ Universiti Malaysia Sarawak, Malaysia \\ e-mail: sallyskaicheen@hotmail.com,azlan@unimas.my
}

Received: 26.07.2021. Revised: 22.12.2021. Accepted: 07.02.2022.

\begin{abstract}
Habitat types are closely associated with altitude gradients in tropical rainforests and play an essential role in species assemblages where terrain heterogeneity is often used to understand effects of climate change on species distribution. The response of larger mammals to habitat variation along altitudes is largely unexplored in Borneo. This study has utilised camera traps to better understand the community structure of larger mammals in Gunung Pueh National Park. Gunung Pueh National Park (1550 m a.s.1.) contains two major habitat types, which include lowland forests $(<1100 \mathrm{~m}$ a.s.1.) and the lower montane $(>1100 \mathrm{~m}$ a.s.1.) forests. The spatio-temporal niches of mid-sized to large-bodied mammal species across these altitude gradients and habitats were assessed. Cameras located at 23 locations, along varying altitude gradients, resulted in 3109 trap nights. Using these cameras, the collected recordings have revealed a total of 22 mid-sized to large-bodied mammals, including 19 species recorded in lowland forest areas, and 18 species in the lower montane forest areas; 15 species were found in both habitats. Four species were exclusively detected in the lowland forest, namely Rusa unicolor, Viverra tangalunga, Presbytis chrysomelas, and Hystrix brachyura. Three species were detected only in the lower montane forest, namely Herpestes semitorquatus, Mustela nudipes, and Hemigalus hosei. In the lowland forest, Macaca nemestrina was recorded with the highest naïve occupancy (naïve $\psi=$ 1.00 ), while Hemigalus derbyanus had the highest naïve occupancy (naïve $\psi=0.93$ ) in the lower montane forest. The temporal diel activity patterns of selected species in the two habitats have shown relatively close similarities, with overlapping patterns ranging between $67-90 \%$. The further conservation of a large area, which encompasses mountainous ranges, is recommended to facilitate the conservation efficacy of such Protected Areas and for supporting diverse, mid-sized to large-bodied mammals in Borneo.
\end{abstract}

Key words: activity pattern, altitude, detection, habitat, occupancy

\section{Introduction}

Montane forests (> $1000 \mathrm{~m}$ a.s.1.) are critical habitats for biodiversity and cover less than $1 \%$ of Sarawak's topography (Hazebroek \& Kashim, 2000; Steinmetz et al., 2008). The unique topography, biotic and abiotic conditions of montane forests harbour high levels of species endemism often categorised as "cooladapted upland species» (Still et al., 1999; Williams et al., 2003). Populations of upland or mountaintop specialists are considered to be incredibly fragile and vulnerable to the effects of climate change (Williams et al., 2003).

Species richness is expected to be different between habitat zones along the altitude gradients due to different habitat complexity. Lowland forests often have taller trees and include a greater diversity of fruiting trees, supporting more large-bodied animals (Hazebroek \& Kashim, 2000; Dalling et al., 2016). Lowland forests are often associated with biodiversity hotspots in the tropics as they are rich in bio- diversity and often exposed to rapid anthropogenic activities (Steinmetz et al., 2008). In contrast, montane forests are less diverse in terms of forest structure and assemblages, where trees are often smaller and more slender in character with leaves being relatively smaller and thicker (Hazebroek \& Kashim, 2000).

Habitat types can affect activity patterns and resource partitioning of species. For example, sympatric species tend to reduce competition through differing their diet, activity rhythm and/ or habitat (Dirzo \& Raven, 2003; Hearn et al., 2018). Furthermore, temporal activity rhythm of larger tropical mammals may also depict their responses towards the synergistic effects of habitat degradation and anthropogenic activities, e.g. a species could be more nocturnal in areas of higher human activity (Griffiths \& Schaik, 1993; Norris et al., 2010). The diel activity pattern of prey species is often also closely associated with their predators. Therefore, shifts in the predator's activity patterns will influence the survival rate 
of their prey species (Griffiths \& Schaik, 1993; Palomares et al., 2016; Hearn et al., 2018).

On Borneo, birds are the most studied vertebrate taxa, with pronounced differences between avian species across altitude zones due to their sensitivity to micro-habitats and their role as bio-indicators (Boyce et al., 2015). However, the distribution of larger mammals along altitude gradients remains to be poorly understood. Additionally, the complexity and the number of shared species between habitats have not been clearly investigated. This study stratified motion-sensor cameras along differing altitude gradients (from $200 \mathrm{~m}$ a.s.1. to $1400 \mathrm{~m}$ a.s.1.), corresponding to two habitat types (lowland forests and lower montane forests) in Gunung Pueh National Park (GPNP). GPNP stretches along the Pueh - Berumput mountain range, which consists of three mountains including Gunung Berumput, Gunung Pueh and Gunung Kanyi. Gunung Kanyi peaks at $1550 \mathrm{~m}$ a.s.l. and is the highest summit in western Sarawak (Fizl et al., 2012). This study was aimed to examine 1) the heterogeneous community structure of mid-sized to large-bodied mammals between lowland forests and lower montane forest in terms of species richness, naïve occupancy and diet behaviours, and 2) the activity patterns of selected species that differ between lowland forests and lower montane forests, where overlaps in community structures between habitat zones were expected.

\section{Material and Methods \\ Data collection}

The sampling site, Gunung (= Mountain) Pueh National Park (GPNP) lies adjacent to the Kalimantan, Indonesia border and was gazetted as a Protected Area in 2005. The total area of GPNP is $58.31 \mathrm{~km}^{2}$ (Fig. 1). It is located in the Lundu district, approximately $100 \mathrm{~km}$ away from Kuching, Sarawak. Being adjacent to GPNP, there are several villages, including the village of Sebako belonging to the Dayak Selakau tribe, by providing an entrance into this mountain range. Parts of the lowland forest areas of GPNP have been selectively logged, but these areas still retain some of the original biodiversity and natural resources utilised often by the surrounding communities. There are oil palm plantations and water catchment areas spread along the foothills of GPNP. GPNP's habitat transitions from lowland forest areas into hilly, dipterocarp forests extending further into lower montane forest areas.
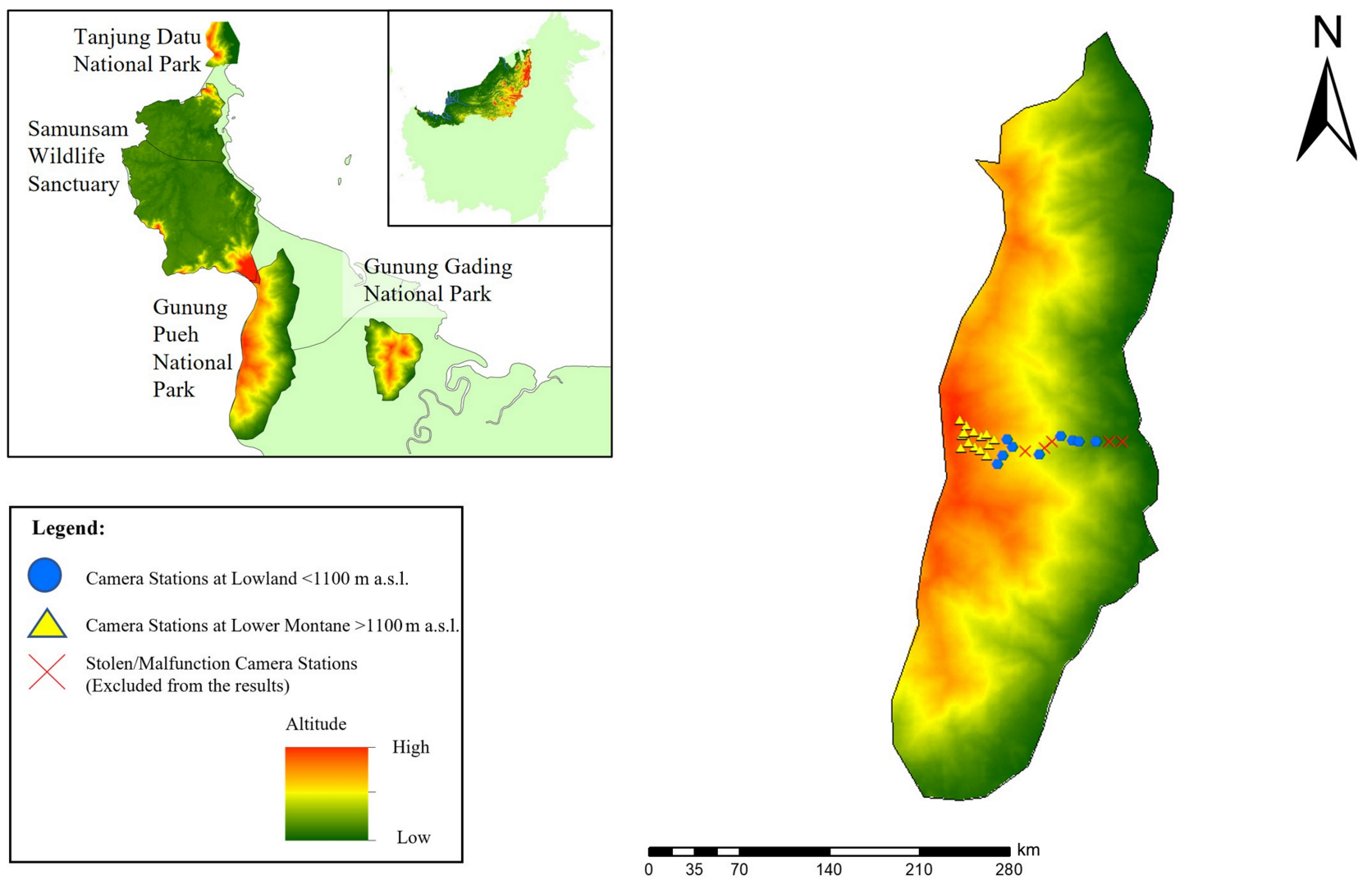

Fig. 1. The map showing the location of Gunung Pueh National Park and the nearest Protected Areas in the surroundings. The camera stations were deployed within two habitat areas: the lowland forests $(<1100 \mathrm{~m}$ a.s.l. $)$ and the lower montane forests $(>1100 \mathrm{~m}$ a.s.1.). 


\section{Camera trapping}

A total of 23 camera traps (excluding four stolen, and one malfunctioned units) were deployed along various altitudes in GPNP from 16.06.2016 to 27.03.2017 (approximately nine months with a total of 3109 camera trap nights). There was no prior knowledge of the species distribution and activity patterns in GPNP that contributed towards camera trap placement. Bushnell® Trophy Cam units (model 119636c) with Passive Infra-Red motion sensors were left operational for $24 \mathrm{~h}$ throughout the sampling period with settings at three photographs per trigger with a 2-min interval between triggers to reduce photo data storage. The timestamp ensured the imprint of date and time, with high sensitivity and resolution being utilised by the 12-megapixel sensors. Camera traps were secured using a lockable metal casing and a python cable, with cameras mounted on a tree around 25-30 cm above the ground. The camera traps were deployed between the altitudinal ranges of 200-1400 $\mathrm{m}$ a.s.l. in two habitat zones (lowland forests on < $1100 \mathrm{~m}$ a.s.l. and the lower montane forests on $>1100$ $\mathrm{m}$ a.s.l. until the peak at $1550 \mathrm{~m}$ a.s.l.) and were relocated after 120-150 days to improve coverage and increase detection rates. The distance between the camera stations were between $500-1000 \mathrm{~m}$ a.s.l. The co-ordinates of camera stations were recorded using Global Positioning System (GPS) with collected photographs, then sorted and identified to the species level. A possible photo of the same species is deemed as an independent photo/event if there was a time gap of approximately $60 \mathrm{~min}$.

\section{Data analysis}

\section{Software}

The sorted photographs to the species level were renamed by the Renamer Lite version 6.8. The renamed photographs were further analysed by CAMERASWEET with function DataOrganize ver. 4.5 and DataAnalyze ver. 6.1 (SWCCF, 2020). The output was used for various analysis through $\mathrm{R}$, ver. 4.0.3 (R Core Team, 2020). The sum of camera-trap days was calculated through the number of active cameras multiplied by the total number of sampling days according to Mohd-Azlan (2006).

\section{Naïve occupancy}

The naïve occupancy was generated through package «wiqid» ver. 0.1.0 (Meredith, 2015). The naïve occupancy was defined as the proportion of sites occupied by a detected species as a number of detected sites divided by a total number of cameratrap sites (Bailey \& Adams, 2005).

\section{Activity patterns}

The relative frequency of photographs captured at different time throughout the spatial sampling in the study area is assumed to be related to the animal activity patterns (Kawanishi, 2002; MohdAzlan, 2006). Activity patterns were created only for species with more than 17 independent events. Species were considered diurnal if activity ranges were between 06:00-18:00 $\mathrm{h}$ and nocturnal if active ranges were between 18:00-06:00 h. Activity patterns were structured, analysed, and illustrated using package «camtrapR» ver. 2.0.3 and «overlap» ver. 0.3.4 (Niedballa et al., 2016; Meredith \& Ridout, 2014). The kernel density estimator was used to assess the area under the sympatric species distribution curve, where $\Delta$ is the actual coefficient of an overlap (Ridout \& Linkie, 2009).

\section{Results \\ Mid-sized to large-bodied mammalian richness in lowland and lower montane forest}

This study has detected a total of 22 mid-sized to large-bodied mammal species, consisting of five orders and ten families (Table). A total of 19 species were recorded in lowland forests $(<1100 \mathrm{~m}$ a.s.1.) across 1451 camera trap nights, while 18 species were recorded in the lower montane forests $(>1100 \mathrm{~m}$ a.s.1.) from 1658 camera trap nights. The lowland forest and lower montane forest shared a total of 15 species. Mammalian richness showed no significant difference between these habitat zones (Mann-Whitney test: $\mathrm{p}=0.217$ ).

Rusa unicolor (Kerr, 1792), Viverra tangalunga Gray, 1832, Presbytis chrysomelas (Müller, 1838), and Hystrix brachyura Linnaeus, 1758 were recorded exclusively within lowland forests, while Herpestes semitorquatus Gray, 1846, Mustela nudipes Desmarest, 1822, and Hemigalus hosei (Thomas, 1892) were recorded exclusively within lower montane forests.

In the lowland forest, Trichys fasciculata (Shaw, 1801) accounted for the highest independent event records $(n=44)$, while Hemigalus derbyanus (Gray, 1837) accounted for the most records $(n=91)$ in the lower montane forest. Solitary records were expressed in the lowland forest by Sus barbatus (Müller, 1838), Rusa unicolor, Martes flavigula (Boddaert, 1785), Arctictis binturong (Raffles, 1821), Paguma larvata (Smith, 1827), Prionodon linsang (Hardwicke, 1821), Pardofelis marmorata (Martin, 1837), Neofelis diardi (Cuvier, 1823), Manis javanica Desmarest, 1822, and Presbytis chrysomelas (Müller, 1838). 
Table. The list of mid-sized to large-bodied mammals recorded in Gunung Pueh National Park showing independent events in lowland forests $(<1100 \mathrm{~m}$ a.s.l.) and lower montane forests $(>1100 \mathrm{~m}$ a.s.l.) with their protection and conservation status

\begin{tabular}{|c|c|c|c|c|c|c|}
\hline \multirow{2}{*}{ Order/Family } & \multirow{2}{*}{ Scientific / common name } & \multicolumn{2}{|c|}{ Independent events } & \multicolumn{3}{|c|}{ Protection and conservation status } \\
\hline & & Lowland forests & Lower montane forests & WLPO, 1998 & IUCN & CITES \\
\hline \multicolumn{7}{|c|}{ Artiodactyla } \\
\hline Suidae & $\begin{array}{l}\text { Sus barbatus } \\
\text { Bearded pig }\end{array}$ & 1 & 4 & - & VU & - \\
\hline Cervidae & $\begin{array}{l}\text { Muntiacus muntjak } \\
\text { Red muntjac }\end{array}$ & 27 & 29 & - & $\mathrm{LC}$ & - \\
\hline Cervidae & $\begin{array}{l}\text { Muntiacus atherodes } \\
\text { Yellow muntjac }\end{array}$ & 6 & 2 & - & NT & - \\
\hline Cervidae & $\begin{array}{l}\text { Rusa unicolor } \\
\text { Sambar deer }\end{array}$ & 1 & 0 & - & VU & - \\
\hline \multicolumn{7}{|c|}{ Carnivora } \\
\hline Herpestidae & $\begin{array}{l}\text { Herpestes brachyurus } \\
\text { Short-tailed mongoose }\end{array}$ & 5 & 2 & $\mathrm{P}$ & NT & - \\
\hline Herpestidae & $\begin{array}{l}\text { Herpestes semitorquatus } \\
\text { Collared mongoose }\end{array}$ & 0 & 2 & $\mathrm{P}$ & NT & - \\
\hline Mustelidae & $\begin{array}{c}\text { Martes flavigula } \\
\text { Yellow-throated marten }\end{array}$ & 1 & 3 & - & $\mathrm{LC}$ & III \\
\hline Mustelidae & $\begin{array}{l}\text { Mustela nudipes } \\
\text { Malay weasel }\end{array}$ & 0 & 2 & - & $\mathrm{LC}$ & - \\
\hline Viverridae & $\begin{array}{l}\text { Arctictis binturong } \\
\text { Binturong }\end{array}$ & 1 & 3 & $P$ & VU & III \\
\hline Viverridae & $\begin{array}{l}\text { Hemigalus derbyanus } \\
\text { Banded palm civet }\end{array}$ & 34 & 91 & $P$ & NT & II \\
\hline Viverridae & $\begin{array}{l}\text { Hemigalus hosei } \\
\text { Hose's civet }\end{array}$ & 0 & 17 & $\mathrm{P}$ & VU & - \\
\hline Viverridae & $\begin{array}{c}\text { Paguma larvata } \\
\text { Masked palm civet }\end{array}$ & 1 & 9 & $\mathrm{P}$ & $\mathrm{LC}$ & III \\
\hline Viverridae & $\begin{array}{l}\text { Viverra tangalunga } \\
\text { Malay civet }\end{array}$ & 2 & 0 & $\mathrm{P}$ & $\mathrm{LC}$ & - \\
\hline Prionodontidae & $\begin{array}{l}\text { Prionodon linsang } \\
\text { Banded linsang }\end{array}$ & 1 & 3 & - & $\mathrm{LC}$ & II \\
\hline Felidae & $\begin{array}{c}\text { Prionailurus bengalensis } \\
\text { Leopard cat }\end{array}$ & 2 & 5 & $P$ & $\mathrm{LC}$ & II \\
\hline Felidae & $\begin{array}{c}\text { Pardofelis marmorata } \\
\text { Marbled cat }\end{array}$ & 1 & 3 & $\mathrm{TP}$ & NT & I \\
\hline Felidae & $\begin{array}{l}\text { Neofelis diardi } \\
\text { Clouded leopard }\end{array}$ & 1 & 3 & $\mathrm{TP}$ & VU & I \\
\hline \multicolumn{7}{|c|}{ Pholidota } \\
\hline Manidae & $\begin{array}{l}\text { Manis javanica } \\
\text { Sunda pangolin }\end{array}$ & 1 & 2 & $\mathrm{P}$ & $\mathrm{CR}$ & I \\
\hline \multicolumn{7}{|c|}{ Primates } \\
\hline Cercopithecidae & $\begin{array}{l}\text { Macaca nemestrina } \\
\text { Pig-tailed macaque }\end{array}$ & 37 & 43 & $\mathrm{P}$ & VU & II \\
\hline Cercopithecidae & $\begin{array}{l}\text { Presbytis chrysomelas } \\
\text { Bornean banded langur }\end{array}$ & 1 & 0 & $\mathrm{P}$ & $\mathrm{CR}$ & - \\
\hline \multicolumn{7}{|c|}{ Rodentia } \\
\hline Hystricidae & $\begin{array}{l}\text { Hystrix brachyura } \\
\text { Malayan porcupine }\end{array}$ & 23 & 0 & $\mathrm{P}$ & $\mathrm{LC}$ & - \\
\hline Hystricidae & $\begin{array}{l}\text { Trichys fasciculata } \\
\text { Long-tailed porcupine }\end{array}$ & 44 & 18 & $\mathrm{P}$ & $\mathrm{LC}$ & - \\
\hline \multicolumn{2}{|c|}{ Total number of independent events } & 190 & 241 & - & - & - \\
\hline \multicolumn{2}{|l|}{ Total species } & 19 & 18 & - & - & - \\
\hline \multicolumn{2}{|l|}{ Total effort } & 1451 & 1658 & - & - & - \\
\hline
\end{tabular}

*Note: WLPO, 1998 - Wild Life Protection Ordinance 1998; IUCN - International Union for Conservation of Nature Red List of Threatened Species (IUCN, 2021); CITES Convention on International Trade in Endangered Species of Wild Fauna and Flora; TP - totally protected wildlife species, P - protected wildlife species, «-» - not available/not recorded; LC - Least Concern, NT - Near Threatened, VU - Vulnerable, EN - Endangered; I - species listed under CITES appendix I, II - species listed under CITES appendix II, III - species listed under CITES appendix III.

Two species recorded were listed as totally protected and 13 species as protected taxa under the Wild Life Protection Ordinance 1998 in Sarawak. Additionally, eight species were listed as Least Concern (LC), five as Near Threatened (NT), five as Vulnerable (VU), and two species as Critically
Endangered (CR) according to the IUCN Red List of Threatened Species (IUCN, 2021). Three species were listed in Appendix I, four species in Appendix II, and three species in Appendix III under the Convention on International Trade in Endangered Species of Wild Fauna and Flora (CITES, 2021). 


\section{Naïve occupancy}

In general, the naïve occupancy of all recorded mid-sized to large-bodied mammals in GPNP did not reach completeness (naïve $\psi \neq 1$ ). All species showed different naïve occupancy between these two habitat zones (Fig. 2). The naïve occupancy of the 19 recorded mid-sized to large-bodied mammals in lowland forest was from 0.11-1.00, where Macaca nemestrina has a completeness ratio with naïve occupancy at 1.00. Six species showed relatively higher naive occupancy in the lowland forest, namely
Herpestes brachyurus, Macaca nemestrina, Manis javanica, Muntiacus atherodes, Muntiacus muntjak, and Trichys fasciculata.

While in the lower montane forest, none of the recorded species reach completeness (naïve $\psi \neq 1$ ). However, nine of the recorded species showed higher naïve occupancy in lower montane forests compared to lowland forests. These species are Arctictis binturong, Hemigalus derbyanus, Martes flavigula, Neofelis diardi, Paguma larvata, Pardofelis marmorata, Prionailurus bengalensis, Prionodon linsang, and Sus barbatus (Fig. 2).

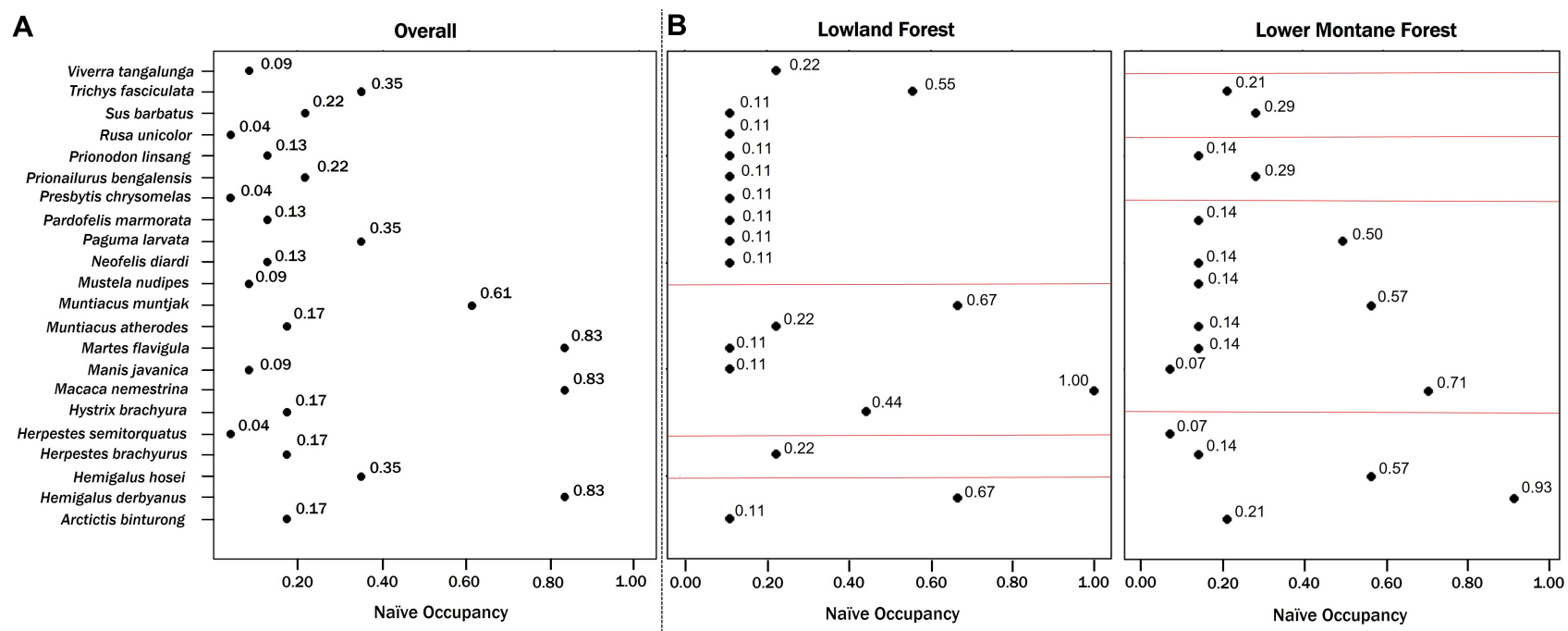

Fig. 2. The naïve occupancy of all recorded mid-sized to large-bodied mammals in general (A) and separately in lowland and lower montane forests (B). Black points indicate the naïve occupancy, while red lines indicate that species was not recorded in the habitat type.

\section{Distribution of dietary guilds}

The recorded mammals have been categorised according to their dietary guilds. Nine species are carnivores (Prionailurus bengalensis, Pardofelis marmorata, Neofelis diardi, Hemigalus hosei, Hemigalus derbyanus, Prionodon linsang, Mustela nudipes, Herpestes semitorquatus, Herpestes brachyura), four are herbivores (Rusa unicolor, Muntiacus muntjak, Muntiacus atherodes, and Presbytis chrysomelas), eight are omnivorous mammals (Trichys fasciculata, Hystrix brachyura, Martes flavigula, Viverra tangalunga, Paguma larvata, Arctictis binturong, Sus barbatus, and Macaca nemestrina) and one is an insectivore species (Manis javanica). Carnivores are predominantly distributed in the lower montane forest (nine in lower montane forests, and six in lowland forests) in GPNP. In contrast, herbivores (four in lowland forests, and two in lower montane forests) and omnivores (eight in lowland forests, and six in lower montane forests) are recorded frequently at lowland forest areas (Fig. 3).

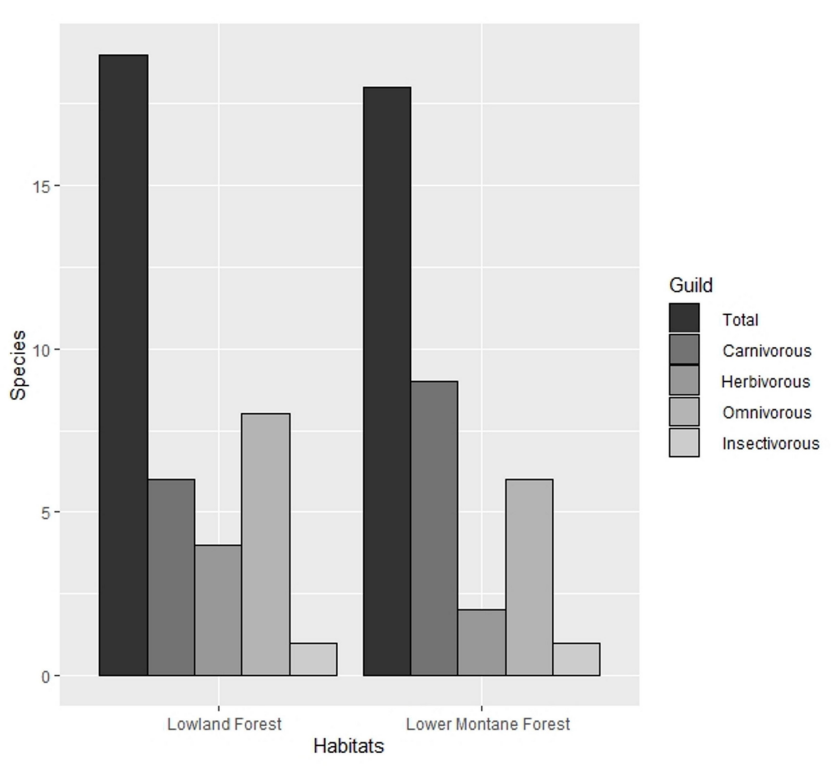

Fig. 3. The mammal species distribution according to guild and habitat type (lowland forests and lower montane forests) in Gunung Pueh National Park. 
Temporal diel activity patterns of selected mid-sized to large-bodied mammals

Comparisons of diel activities between the two habitats were conducted in relation to four species (Muntiacus muntjak, Hemigalus derbyanus, Macaca nemestrina, and Trichys fasciculata). The temporal diel activity patterns of these four species showed a relatively high degree of overlap (67-90\%) and did not differ species-specifically between lowland forests and lower montane forests surveyed (Fig. 4). Muntiacus muntjak showed a crepuscular activity pattern and recorded an overlap of $67 \%$ between the two habitats (Fig. 4). Macaca nemestrina exhibited diurnal characteristics and recorded a relatively high overlap $(87 \%)$ between the two habitats (Fig. 4). Like Muntiacus muntjak, Macaca nemestrina in the lower montane forest had

a)

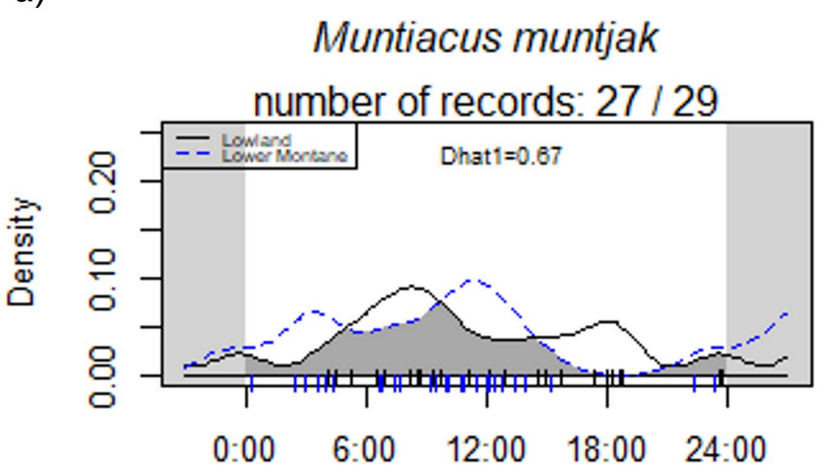

Time

c)

Macaca nemestrina

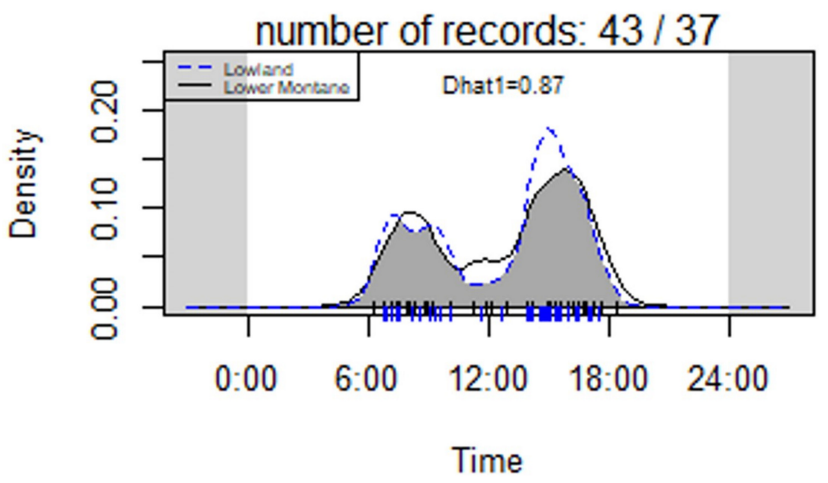

a later diurnal activity peak compared to the lowland forest.

\section{Discussion}

Gunung Pueh National Park showed the highest number of mid-sized to large mammals (22 species) in comparison to the nearest Protected Areas (Samunsam Wildlife Sanctuary, Tanjung Datu, and Gunung Gading National Park), where each area is represented by only 20 species (Mohd-Azlan et al., 2018b, 2019, 2020). GPNP demonstrated 13 carnivore species, while Gunung Gading National Park, Samunsam Wildlife Sanctuary and Tanjung Datu National Park recorded 12, nine and seven species, respectively. This study also extends the known distribution of Hemigalus hosei in the western Sarawak, with the species previously thought to be locally extinct in this area (Fig. 5a,b) (Jennings et al., 2013; IUCN, 2021).

b)

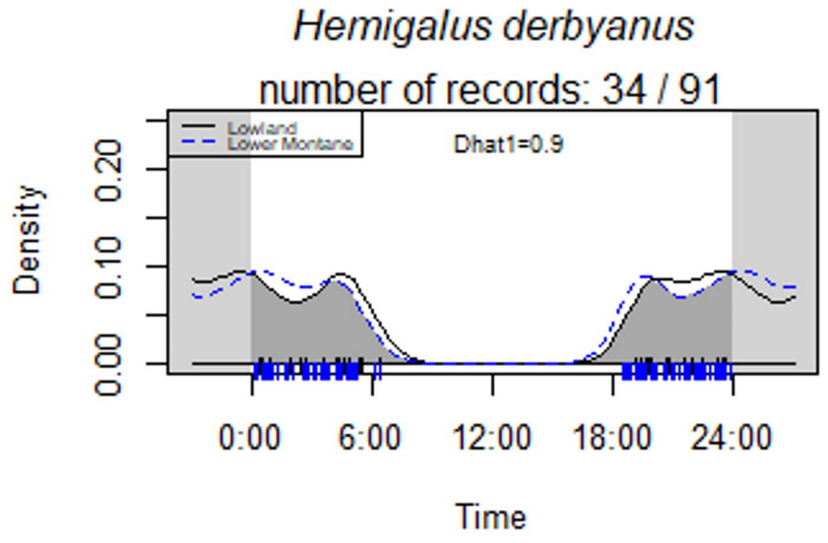

d)

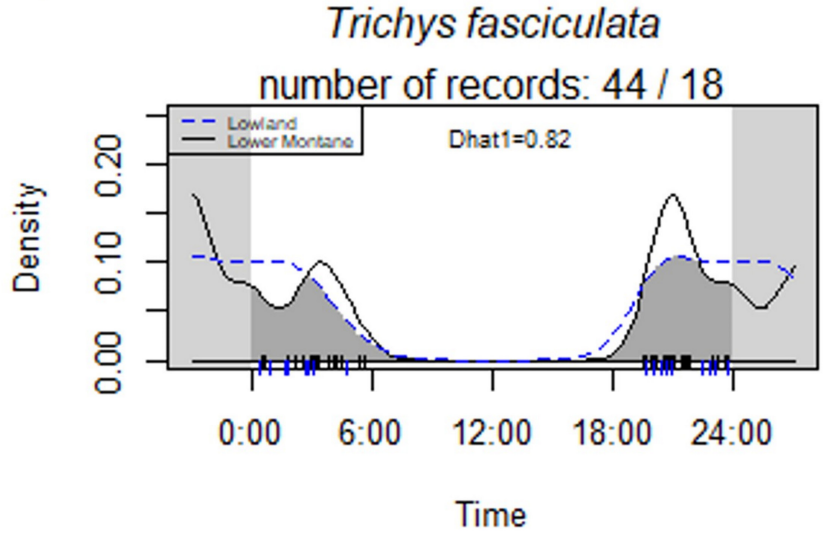

Fig. 4. Comparison of the estimated temporal diel activity patterns between tropical lowland forests and lower montane forests in relation to a) Muntiacus muntjak, b) Hemigalus derbyanus, c) Macaca nemestrina, d) Trichys fasciculata. The number of records represents the total number of independent events for a certain species in the particular habitat type. The shaded area under the curves indicates the degree of overlap between tropical lowland forests and lower montane forests. The vertical lines below the graph infer the density of photographs taken. 

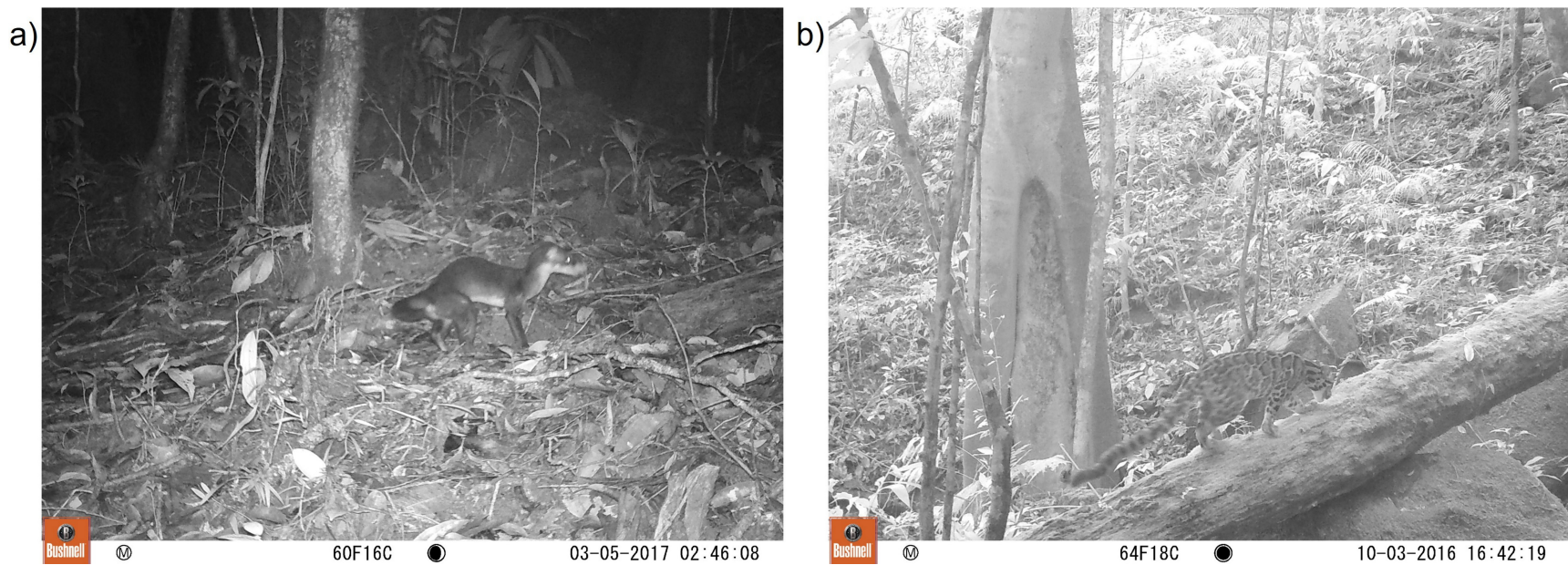

Fig. 5. Recent sightings of a) Hemigalus hosei and b) Neofelis diardi in Gunung Pueh National Park, Kuching, Western Sarawak.

Approximately $27 \%$ of the mammals had a higher naïve occupancy in lowland forests compared to lower montane forests, while $41 \%$ of the recorded mammals showed a higher naïve occupancy in lower montane forests. This phenomenon could be attributed to the proliferation of anthropogenic activities at lowland forest areas causing species to move upwards. The increased intensity of edge effects creates unfavourable environments for species (e.g. carnivores and ungulates) whereby species become avoidant (Brodie et al., 2015; Mohd-Azlan et al., 2018a). Fragmentation also restricts the movement of primates and arboreal animals (Michalski \& Peres, 2005; Brodie et al., 2015; Mohd-Azlan et al., 2018a). Additionally, hunting by nearby local communities adjacent to Protected Areas could partly contribute to this finding. In Sarawak, local communities are allowed to hunt non-protected species for subsistence outside Protected Areas. Hence, these factors may further contribute to the movement of some mammals towards safer ground (e.g. higher areas). However, species richness of mid-sized to large-bodied mammals did not differ significantly between lowland and lower montane forest areas $(\mathrm{p}>0.05)$.

Most generalist species that have a higher tolerance to disturbance (e.g. Prionailurus bengalensis and Trichys fasciculata) were recorded in both habitats, while some species that were more sensitive were only detected in a single habitat (e.g. Hemigalus hosei and Hystrix brachyura). Hemigalus hosei was recorded exclusively at the lower montane forest in this study with naïve $\psi=0.57$ (Fig. 2) and their distribution was considered to be closely associated with high- land habitats, mainly being recorded historically in evergreen forests, hilly lands, mountainous terrains, and some forest patches within logging concessions (Wilting \& Fickel, 2012; Jennings et al., 2013; IUCN, 2021). Hemigalus derbyanus had a higher naïve occupancy in the lower montane forest ( $>1100 \mathrm{~m}$ a.s.1.), contradicting the findings from Jennings et al. (2013), who suggested that this species prefers lowland forest areas by avoiding inter-competition with the sympatric Hemigalus hosei (Fig. 2). However, Hemigalus derbyanus does seem to have a wider altitude range preference compared to Hemigalus hosei, as this study recorded the species in both habitat types (Table 1).

Evolution and natural selection have created divergences in the dietary behaviours of mammals due to resource partitioning (Simberloff, 1998; Tobler et al., 2008). In this study, a greater number of carnivores were recorded within the lower montane forests compared to the lowland forests. In contrast, herbivorous and omnivorous mammals preferred lowland forest areas, potentially for the purpose of predator avoidance or due to the reduced resources and camouflage cover in lower montane forest areas (Steinmetz et al., 2008).

Activity patterns are widely used in species ecology in relation to understand temporal partitioning (Norris et al., 2010). The diel activity patterns of four selected species display a $67-90 \%$ similarity between lowland forests and lower montane forests. Muntiacus muntjak demonstrates the peak of activity into later hours $(12: 00 \mathrm{~h})$ in the lower montane forest compared to lowland areas $(10: 00 \mathrm{~h})$. Peak activity timing for species in lowland forests areas appears to 
be much earlier than from the lower montane forest (Fig. 4). This could be caused by the difference in ambient temperatures, such as at afternoon $(12: 00 \mathrm{~h})$, where the highest ambient temperature for lowland forests is $27^{\circ} \mathrm{C}$, while for lower montane forests, it is $21^{\circ} \mathrm{C}$. The similarity between activity patterns denote that some mammals could potentially extend their altitude ranges into both habitat types by adjusting their active hours. However, this would ultimately affect upland species, which are forced to move higher to avoid inter-competition and may consequently become locally extinct due to a reduction of habitat size and resources.

The combined temporal-spatial analyses of this study provide information on potential temperature sensitivity and the ability for distributional plasticity of mammals in GGNP. Understanding altitude range shifts in animals is further complicated as upward changes in temperature regimes do not necessarily coincide with changes in plant distribution (Brodie et al., 2017). This study has recorded some of the rarest mammal species in Sarawak, such as the elusive Hemigalus hosei and Neofelis diardi, rationalising calls for conservation prioritisation for highlands nearby populated areas. Despite Sarawak holding approximately $8674.18 \mathrm{~km}^{2}$ of terrestrial Protected Areas, highland areas are often poorly represented in this Protected Area network. However, the results should be carefully interpreted as it is based on a small sample-size. Further research should be conducted in similar fragile habitats to better understand the distribution and conservation needs of highland specialists.

\section{Acknowledgements}

We would like to express our gratitude to the Malaysia Ministry of Higher Education under Niche Research Grant Scheme (NRGS/1087/2013(01)) for their financial support; Sarawak Forestry Department for the permission (issue number NCCD.907.4.4(JLD.11)-17), Park Permit Number WL 021/2015 and NCCD.907.4.4(JLD.13)-219, Park Permit Number WL 009/2016; and the Programme Animal Resource Science and Management, Universiti Malaysia Sarawak (UNIMAS) for the field assistance, transportation, and equipment. We would also like to express our most profound appreciation to Mr. Trevor Allen, Ms. Melynda Cheok, Mr. Shafri Semawi for their assistance in the field. We thank Ms. Lisa Lok Choy Hong and Mr. Anthony Pine (Institute of Biodiversity and Environmental Conservation, Sarawak, Malaysia) for proofreading and the anonymous reviewers for their helpful reviews and comments that greatly improved the manuscript.

\section{References}

Bailey L., Adams M.J. 2005. Occupancy models to study wildlife. USGS Fact Sheet 2005-3096, Reston: U.S. Geological Survey. 6 p. DOI: 10.3133/fs20053096

Boyce M.S., Johnson C.J., Merrill E.H., Nielsen S.E., Solberg E.J., van Moorter B. 2015. Can habitat selection predict abundance? Journal of Animal Ecology 85(1): 11-20. DOI: 10.1111/1365-2656.12359

Brodie J., Giordano A.J., Ambu L. 2015. Differential responses of large mammals to logging and edge effects. Mammalian Biology 80(1): 7-13. DOI: 10.1016/j.mambio.2014.06.001

Brodie J.F., Strimas-Mackey M., Mohd-Azlan J., Granados A., Bernard H., Giordano A.J., Helmy O.E. 2017. Lowland biotic attrition revisited: body size and variation among climate change 'winners' and 'losers'. Proceedings of the Royal Society B: Biological Sciences 284(1847): 20162335. DOI: 10.1098/rspb.2016.2335

CITES. 2021. Convention on International Trade in Endangered Species of Wild Fauna and Flora Appendices I, II, and III. Available from https://cites.org/eng/ app/appendices.php

Dalling J.W., Heineman K., González G., Ostertag R. 2016. Geographic, environmental and biotic sources of variation in the nutrient relations of tropical montane forests. Journal of Tropical Ecology 32(5): 368 383. DOI: $10.1017 /$ S0266467415000619

Dirzo R., Raven P.H. 2003. Global state of biodiversity and loss. Annual Review of Environment and Resources 28(1): 137-167. DOI: 10.1146/annurev.energy.28.050302.105532

Fizl M., Ramji S., Pui Y.M., Ridwan M., Rahman A., Mustapha A.R. 2012. Rediscovery of the Enigmatic Mountain Blackeye, Chlorocharis emiliae Sharpe, 1888 (Passeriformes: Zosteropidae) from Mount Pueh, Sarawak. Tropical Natural History 12(2): 261-266.

Griffiths M., Schaik C.P. 1993. The impact of human traffic on the abundance and activity periods of Sumatran rain forest wildlife. Conservation Biology 7(3): 623626. DOI: 10.1046/j.1523-1739.1993.07030623.x

Hazebroek H.P., Kashim A.M. 2000. National Parks of Sarawak. Kota Kinabalu, Sabah, Malaysia: Natural History Publications. 502 p.

Hearn A.J., Cushman S.A., Ross J., Goossens B., Hunter L.T., Macdonald D.W. 2018. Spatio-temporal ecology of sympatric felids on Borneo. Evidence for resource partitioning? PloS ONE 13(7): e0200828. DOI: $10.1371 /$ journal.pone.0200828

IUCN. 2021. IUCN Red List of threatened species. Version 2017-3. Gland, Switzerland: International Union for Conservation of Nature. Available from www.iucnredlist.org

Jennings A.P., Mathai J., Brodie J., Giordano A.J., Veron G. 2013. Predicted distributions and conservation 
status of two threatened Southeast Asian small carnivores: the banded Civet and Hose's Civet. Mammalia 77(3): 261-271. DOI: 10.1515/mammalia-2012-0110

Kawanishi K. 2002. Population status of tigers (Panthera tigris) in a primary rainforest of Peninsular Malaysia. PhD Thesis. USA: University of Florida Gainesville. 126 p.

Meredith M. 2015. Wiqid: Quick and Dirty Estimates for Wildlife Populations. R package, version 0.1.0. Available from: https://cran.r-project.org/web/packages/wiqid/index.html

Meredith M., Ridout M. 2014. Overview of the overlap package. Available from www.cran.r-project.org/ web/packages/overlap

Michalski F., Peres C.A. 2005. Anthropogenic determinants of primate and carnivore local extinctions in a fragmented forest landscape of southern Amazonia. Biological Conservation 124(3): 383-396. DOI: 10.1016/j.biocon.2005.01.045

Mohd-Azlan J. 2006. Mammal diversity and conservation in a secondary forest in Peninsular Malaysia. Biodiversity and Conservation 15(3): 1013-1025. DOI: 10.1007/s10531-004-3953-0

Mohd-Azlan J., Kaicheen S.S., Yoong W.C. 2018a. Distribution, relative abundance and occupancy of selected mammals along paved road in Kubah National Park, Sarawak, Borneo. Nature Conservation Research 3(2): 36-46. DOI: 10.24189/ncr.2018.028

Mohd-Azlan J., Nurul-Asna H., Jailan T.S., Tuen A.A., Engkamat L., Abdillah D.N., Zainudin R., Brodie J.F. 2018b. Camera trapping of terrestrial animals in Tanjung Datu National Park, Sarawak, Borneo. Raffles Bulletin of Zoology 66: 587-594.

Mohd-Azlan J., Kaicheen S.S., Lok L., Brodie J.F. 2019. Diversity and size-structured persistence of tropical carnivores in a small, isolated protected area. Mammalia 84(1): 34-40. DOI: 10.1515/mammalia-2018-0041

Mohd-Azlan J., Lok L., Maiwald M.J., Fazlin S., Shen T.D., Kaicheen S.S., Dagang P. 2020. The distribution of medium to large mammals in Samunsam Wildlife Sanctuary, Sarawak in relation to the newly constructed Pan-Borneo Highway. Nature Conservation Research 5(4): 43-54. DOI: 10.24189/ncr.2020.055

Niedballa J., Sollmann R., Courtiol A., Wilting A. 2016. camtrapR: an R package for efficient camera trap data management. Methods in Ecology and Evolution 7(12): 1457-1462. DOI: 10.1111/2041-210X.12600
Norris D., Michalski F., Peres C.A. 2010. Habitat patch size modulates terrestrial mammal activity patterns in Amazonian forest fragments. Journal of Mammalogy 91(3): 551-560. DOI: 10.1644/09-mamm-a-199.1

Palomares F., Fernández N., Roques S., Chávez C., Silveira L., Keller C., Adrados B. 2016. Fine-scale habitat segregation between two ecologically similar top predators. PloS ONE 11(5): e0155626. DOI: 10.1371/journal.pone.0155626

R Core Team. 2020. R: A language and environment for statistical computing. Vienna, Austria: R Foundation for Statistical Computing. Available from: https://www.R-project.org/

Ridout M.S., Linkie M. 2009. Estimating overlap of daily activity patterns from camera trap data. Journal of Agricultural, Biological, and Environmental Statistics 14(3): 322-337.

Simberloff D. 1998. Flagships, umbrellas, and keystones: is single-species management passé in the landscape era? Biological Conservation 83(3): 247-257. DOI: 10.1198/jabes.2009.08038

Steinmetz R., Chutipong W., Seuaturien N., Chirngsaard E. 2008. Community Structure of Large Mammals in Tropical Montane and Lowland Forest in the Tenasserim-Dawna Mountains, Thailand. Biotropica 40(3): 344-353. DOI: 10.1111/j.1744-7429.2007.00367.x

Still C.J., Foster P.N., Schneider S.H. 1999. Simulating the effects of climate change on tropical montane cloud forests. Nature 398(6728): 608-610. DOI: $10.1038 / 19293$

SWCCF. 2020. Small Wild Cat Conservation Foundation. Available from www.smallcats.org/

Tobler M., Carrillo-Percastegui S., Leite Pitman R., Mares R., Powell G. 2008. An evaluation of camera traps for inventorying large- and medium-sized terrestrial rainforest mammals. Animal Conservation 11(3): 169-178. DOI: 10.1111/j.1469-1795.2008.00169.x

Williams S.E., Bolitho E.E., Fox S. 2003. Climate change in Australian tropical rainforests: an impending environmental catastrophe. Proceedings of the Royal Society B: Biological Sciences 270(1527): 1887-1892. DOI: $10.1098 / \mathrm{rspb} .2003 .2464$

Wilting A., Fickel J. 2012. Phylogenetic relationship of two threatened endemic viverrids from the Sunda Islands, Hose's Civet and Sulawesi civet. Journal of Zoology 288(3): 184-190. DOI: 10.1111/j.14697998.2012.00939.x 


\title{
СТРУКТУРА СООБЩЕСТВ СРЕДНИХ И КРУПНЫХ МЛЕКОПИТАЮЩИХ В ТРОПИЧЕСКИХ НИЗИННЫХ И НИЗКОГОРНЫХ ЛЕСАХ В НАЦИОНАЛЬНОМ ПАРКЕ ГУНУНГ ПУЭ, ЗАПАДНЫЙ САРАВАК, БОРНЕО
}

\author{
С. С. Каичеен ${ }^{\mathbb{D}}$, Дж. Мохд-Азлан \\ Университет Малайзии Саравака, Малайзия \\ e-mail: sallyskaicheen@hotmail.com,azlan@unimas.my
}

\begin{abstract}
Типы местообитаний тесно связаны с перепадом высот в тропических лесах и играют важную роль в сообществах видов, где неоднородность рельефа часто используется для понимания влияния изменения климата на распространение видов. Реакция крупных млекопитающих на изменение среды обитания в зависимости от высоты над уровнем моря практически не изучена на Борнео. В этом исследовании использовались фотоловушки, чтобы лучше понять структуру сообщества крупных млекопитающих в национальном парке Гунунг Пуэ. Национальный парк Гунунг Пуэ (1550 м н.у.м.) включает два основных типа местообитаний, которые представлены низинными лесами $(<1100$ м н.у.м.) и низкогорными лесами (> 1100 м н.у.м.). Были оценены пространственно-временные ниши видов средних и крупных млекопитающих в этих высотных градиентах и местообитаниях. Фотоловушки, расположенные в 23 точках с разным уклоном, позволили получить данные за 3109 фотоловушко-ночей. С помощью этих фотоловушек были собраны данные о 22 видах средних и крупных млекопитающих в общей сложности, в том числе 19 видов в низинных лесах и 18 видов в низкогорных лесах; 15 видов было отмечено в обоих местообитаниях. Четыре вида были обнаружены исключительно в низинных лесах, а именно Rusa unicolor, Viverra tangalunga, Presbytis chrysomelas и Hystrix brachyura. Три вида были обнаружены только в низкогорных лесах, а именно Herpestes semitorquatus, Mustela nudipes и Hemigalus hosei. В низинном типе леса Macaca nemestrina была отмечена с самой высокой простой заселенностью ( $\psi=1.00)$, в то время как у Hemigalus derbyanus была отмечена самая высокая простая заселенность $(\psi=0.93)$ в низкогорном лесу. Временные модели активности отдельных видов в обоих типах местообитаний показали относительно близкое сходство, подтвержденное перекрытием перекрывающихся моделей в диапазоне от $67 \%$ до $90 \%$. Дальнейшее сохранение большой территории, охватывающей горные хребты, рекомендуется для повышения эффективности сохранения таких особо охраняемых природных территорий и для поддержки популяций средних и крупных млекопитающих на Борнео.
\end{abstract}

Ключевые слова: активность, биотоп, высота над уровнем моря, обнаружение, размещение 